\title{
Compliance, governança, riscos, controles internos e proteção de dados com enfoque na integridade e humanização na área da saúde
}

Recebido: 28 jan 2019 Aceito: 10 fev 2019

Autor de correspondência: juliana.nascimento7@yahoo. com.br

Conflito de interesses: Os autores declaram não haver nenhum interesse profissional ou pessoal que possa gerar conflito de interesses em relação a este manuscrito.

\author{
Juliana Oliveira NASCIMENTO ${ }^{(1)}$
}

(1)Unimed Cuiabá, Cuiabá, MT, Brasil.

\section{Resumo}

Nos dias atuais, tema recorrente é a abordagem acerca do compliance, riscos, governança corporativa e controles internos. Como atuação em conformidade, integridade e boa-fé nos negócios, com o propósito de mitigar os riscos, além de detectar e sanar, quaisquer desvios, fraudes, irregularidades e atos de corrupção. Salienta-se que o compliance foi fortemente estabelecido no país, com o advento da Lei Anticorrupção, Lei n. ${ }^{\circ}$ 12.846/2013, regulamentada pelo Decreto n. ${ }^{\circ}$ 8.420/2015). Salienta-se, que os temas acima não possuem somente vertente citada acima, mas, também uma forte atuação em mercados altamente regulados como o da saúde. A saúde no Brasil "é direito de todos e dever do Estado, garantido mediante políticas sociais e econômicas que visem à redução do risco de doença e de outros agravos e ao acesso universal e igualitário às ações e serviços para sua promoção, proteção e recuperação" (Art. 196 CF). Sob este ponto de vista o direito à saúde se encontra num campo de suma importância, abrangendo, assim, a conservação e a preservação de uma vida saudável (completo bem-estar físico, mental e social). Logo, com este direito sendo garantido atenta-se ao fiel cumprimento de um dos princípios basilares da Constituição Federal, a dignidade da pessoa humana. Desta forma, concebe-se que na área da saúde o compliance, riscos, governança corporativa e controles internos tem uma significativa influência regulatória e se apresenta de uma forma um pouco diferenciada de outros mercados, visto que a área da saúde está submetida a legislações específicas em âmbito municipal, estadual e federal. Com robusta ação regulatória do Ministério da Saúde, principalmente de autarquias como a Agência Nacional de Saúde Suplementar (como se observa com nova a promulgação da RN 443/2019) e Agência Nacional de Vigilância Sanitária Anvisa, além dos órgãos de classe. Diante disso, quando se fala em compliance na esfera da saúde há de se enfatizar, primordialmente, a importância da consolidação da governança corporativa que teve o seu início nas organizações na década de 90, quando a revista "The Economist" mencionou pela primeira vez o termo Corporate Governance. A governança corporativa hoje se faz proeminente e diversos estudos têm apresentado a sua importância para agregar valor nas organizações e possui como princípios basilares a equidade, a transparência, a accountabillity e a responsabilidade, conglomerando também o compliance. Deste modo, a consolidação de uma boa governança corporativa contribui muito para a sustentabilidade e perenidade da instituição e, quando se trata de saúde, deve ser aplicada sob a perspectiva também da governança 
clínica. A governança clínica consiste em um sistema métodos aplicados na gestão, para a melhoria contínua da assistência à saúde, sendo desenvolvida a partir das melhores práticas. Com isso, criando ambientes e processos materializados em elevados níveis de qualidade e segurança, com foco na excelência do atendimento e nos cuidados clínicos ao paciente. Sendo que a sua aplicação se iniciou no National Health System - NHS do Reino Unido. Neste prisma, a governança clínica está pautada nos seguintes princípios: responsabilidade (social, clínica, das pessoas, de melhoria); promoção da qualidade (desenvolvimento de protocolos, eficácia do cuidado, melhores práticas, melhoria de assistência, serviços eficazes); educação (compartilhamento, correção de desempenho, desenvolvimento, dispositivos educacionais, fertilização de ideias, mudanças); monitoramento clínico (acompanhamento, avaliação dos procedimentos, regulação da prática médica, revisão clínica); gestão (de pessoas, de processos, com ação); dimensão sistêmica (suporte, sustentabilidade, rede de apoio à distância); e segurança no cuidado (gerenciamento de risco e ambiente seguro), consoante indica Romeu Gomes. Diante disso, esclarece-se que a governança corporativa está mais centralizada no autogoverno da organização, bem como, nos aspectos de gestão administrativa. A governança clínica, por sua vez, tem enfoque na gestão clínica, relacionada aos pontos mais técnicos no que se atine à excelência, segurança e humanização das atividades desenvolvidas em saúde diretamente aplicadas em quem se encontra no final dos processos ali desenvolvidos: o paciente. Enfatiza-se que ambas, quando se trata da área de saúde, devem ser alinhadas a atuarem com conjunto, pois se complementam. Por conseguinte, as duas se convergem ao compliance. Nesta perspectiva, pode-se destacar o grande valor da implementação efetiva e conjunta da governança corporativa, clínica, riscos, compliance, controles internos e agora também Data Protection (Lei 13.709/2018) convergindo tudo isso em um Programa de Integridade Corporativa completo em todas as organizações de saúde sejam públicas ou privadas, de modo contribuir com a transparência entre todos os atores integrantes do sistema. A saúde no Brasil denota a necessidade de premente mudança para melhor eficiência do sistema, bem como para assegurar a sua sustentabilidade. Diante do exposto, na saúde o olhar de quem atua com governança e compliance deve ser amplo tanto na área administrativa quanto operacional (assistência). Ressalta-se que quando da implementação de um sistema de integridade em saúde este deve ser planejado de forma a alcançar a humanização e a segurança do paciente, em consonância à apreciação dos aspectos regulatórios, além da prevenção de riscos, fraudes, combate a corrupção e a proteção de dados. Com isso, buscando as melhores práticas em saúde, sempre com enfoque na pessoa que se encontra como beneficiário final deste processo: o paciente. Afinal, quando se trata de vida a excelência, dignidade, segurança, qualidade e, principalmente, a integridade, bem como, a humanização são cruciais.

Descritores: Governança; Humanização da Assistência; Governança Clínica. 